Christopher Hutton*

\title{
Linguistics and the state: How funding and politics shape a field
}

https://doi.org/10.1515/ijsl-2020-2079

Abstract: In this contribution, Christopher Hutton discusses how states have historically taken an interest in, and funded, linguistics research. For a range of political purposes - including colonial rule and military strategy - knowing about and learning the language of "others" has been part of the projection and use of power. The specific purposes and forms of state support for research on language, argues Hutton, does vary depending on whether states have authoritarian or liberal democratic regimes.

Keywords: linguistics and the state, Cold War, colonial linguistics, authoritarian versus liberal states, history of sociolinguistics

The history of linguistics has generally been written as if the state did not exist, except as an identifying location for a particular author, school, or university. Narratives of the history of linguistics are primarily histories of ideas, whether within a particular national space, in relation to a fundamental idea such as structuralism, or in a broader historical sweep. Some histories focus on neglected figures, theory groups or schools, or factional infighting in a particular period; others offer conceptual history or take the historiography of linguistics itself as an object of study.

By the state I mean a mode of governance, an institution, and the initiator, funder, and regulator of other institutions, including those devoted to knowledge production. The modern state is in this sense both the producer of institutional knowledge, in that the creation of knowledge is largely a public affair, and the consumer of such products, in that, at least to some degree, knowledge produced by universities and research institutes is meant to benefit the state itself as well as its citizens. The underlying question is: Why should the state fund research in linguistics, and, if it is to fund such research, what kind of linguistics should it be, and who should determine the relevant purposes and institutional forms?

*Corresponding author: Christopher Hutton, University of Hong Kong, Hong Kong, China, E-mail: chutton@hku.hk 


\section{Early state interest in linguistics}

One of the rare references to state funding in a work of linguistic theory can be found in the preface to Geoffrey Sampson's Schools of Linguistics. Sampson (1980) denies that "linguistics has any contribution to make to the teaching of English or the standard European languages," commenting: "This would not matter, were it not for the extent to which the 'applied linguistics' industry, like so many other dubious modern enterprises, is financed not by those who see it as having some value but by taxpayers helpless in the grip of a voracious and tyrannical state." (p.11-12) Yet, throughout modern Western history the state has made use of the study of linguistics.

States have strategic interests in the production of particular forms of knowledge, though there is no guarantee that the knowledge produced will be directly useful or reducible to policy goals. The study of non-European languages, the development of writings systems, nomenclatures, and typological classifications, went hand-in-hand with the formalization of European empires, but the imperial project was itself internally conflicted about its methods, aims, and institutions. It is interesting to compare the treatment of early British colonial linguistics in India (figures such as Sir William Jones, 1746-1794, and Henry Thomas Colebrooke, 1765-1837) in standard histories of linguistics with those written within a postcolonial frame. ${ }^{1}$ The first approach underreads British colonialism, presenting it as the mere backdrop to academic investigations; the other perhaps overreads the colonial frame to imply an underlying coherence of strategic purpose that is in part a retrospective construct, drawing its force from the subsequent formalization and institutionalization of British colonial control over India. After all, the School of Oriental Studies (now the School of African and Oriental Studies) was founded in 1916 rather than 1816.

A more familiar topic is US military funding of linguistics research at MIT in the 1960s, apparently offered under the premise that voice recognition technology with military applications would be promoted by formal linguistic analysis. Given that some of this work was conducted within the Chomskyan framework, and Chomsky's own longstanding hostility to the US militaryindustrial complex, this issue has recently flared up into a wide-ranging controversy. ${ }^{2}$ The imbrication of linguistics, military institutions, and intelligence agencies goes however much deeper. In World War II linguists in the United States were engaged in teaching strategic languages and producing

1 Compare Robins (1997), A Short History of Linguistics with Cohn (1996), Colonialism and Its Forms of Knowledge: The British in India.

2 See Knight (2018) and materials at scienceandrevolution.org. 
materials, as well as involved in communications intelligence (cryptanalysis). ${ }^{3}$ The US Army established an Intensive Japanese Language School at the University of Michigan in 1942. The Yale linguist Bernard Bloch and Eleanor Jorden produced a two-volume guide to spoken Japanese that year, published by the United States Armed Forces Institute. Richard Smith states that "World War II Intensive Language and Army Specialized Training Programs in the USA [...] underlay the establishment of Applied Linguistics in the immediate postwar years." ${ }^{4}$ Similarly, area studies, including the linguistics of key languages, is generally viewed as a product of Cold War understandings of strategic knowledge. Today, corpus linguistics is a forensic tool in the analysis of communications intercepted or stored by governments. Linguists are also involved in the state's assessing of migrant and asylum-seeker claims to certain national or ethnic identities.

\section{Approaches to linguistics: Authoritarian vs. democratic states}

In authoritarian states, there are overt mechanisms for regulating the production of knowledge and foregrounding the state's own pragmatic and ideological interests. Paradoxically, this is completely transparent, since there is no pretense that universities are autonomous intellectually, and no official discourse praising liberal values of dissent, the free market of ideas, and the pursuit of knowledge for its own sake. For an authoritarian government, the notion that publicly funded institutional knowledge should call its core ideology into question is anathema. The history of linguistics in the People's Republic of China is primarily one of contributing to state-building, in projects such as the simplification of the writing system, the promotion of the national standard, Putonghua, and the classification, labeling, description, and engineering of minority languages. Post-1975 Vietnamese ethnography and ethnolinguistics is likewise inseparable from state-building, not least because, as in China, the state mandates a set of ethnic identity categories to which all citizens are assigned.

3 See Betty Birner, "FAQ: Linguistics and National Security," Linguistics Society of America, https://www.linguisticsociety.org/resource/faq-linguistics-and-national-security.

4 Richard Smith, “'Developing the History of Applied Linguistics': Introductory Remarks," University of Warwick. https://warwick.ac.uk/fac/soc/al/research/collections/elt_archive/pre sentations/developing_history_of_applied_linguistics/ last modified February 27, 2019. 
In liberal democracies, by contrast, the relationship between the state, institutional interests (both public and private), and knowledge production is much murkier. Democratic polities formally recognize the importance of dissent, for example in the plurality of political parties and the role of the media in scrutinizing government policy. For the government to dictate the fundamental direction and framework within which academic research should be constructed goes against the liberal recognition of the value of dissent, and reflects the idea that knowledge should not be seen purely instrumentally, that there are societal benefits to the free circulation of ideas, and that there is an intrinsic value to intellectual exploration and skeptical inquiry. Yet the principle of democratic accountability also suggests that university research should serve the polity as a whole, and not merely reflect the private interests and concerns of the researcher. The institution and the individual researcher must be held accountable to the state and the taxpayer who is funding the public sector.

State funding of academic research is often mediated through semiautonomous funding bodies, such as the National Endowment for the Humanities in the United States or the Research Grants Council in Hong Kong. ${ }^{5}$ In public systems under managerial modes of governance (the United Kingdom, Australia, New Zealand, Hong Kong), forms of relevance are mandated for university research, including the humanities, in terms of "impact." This is understood as a demonstrably causal connection between a scholar's intellectual work and changes in practice by a public body, civil society agency, or commercial firm. In the case of linguistics, this might mean changes in language policy in education or in the workplace, or reform to police interviewing procedures. Private tertiary institutions are not exempt, as they draw on public research funds and need to be accredited by state bodies, though long-established elite universities can afford to maintain areas of inquiry that do not attract large numbers of students, such as Indo-European linguistics.

In authoritarian systems, the institutional politics of the state is on the surface, and one needs to look beneath that surface to find the tensions and ambivalences in the scholarship. In liberal systems, the tensions are implicit in the mediation between state funding, philanthropic, and corporate interests, and notionally free intellectual inquiry. This academic freedom, as Monica Heller's introductory essay shows, in the case of the SSRC's Committee on Sociolinguistics was in the hands of a "closed-network," funded through the SSRC from 1963 to 1979.

5 Monica Heller's introductory essay illustrates another variant in which private philanthropy plays a role in funding academic research by providing funds to a nonprofit (the Social Science Research Council), which then disbursed funds. 
One important observation that Heller makes is that the committee was instrumental in shifting the focus of research from global developmental issues and postcolonial state-building to domestic concerns that reflected the rise of oppositional or countercultural identity politics, and discrimination and inequality within the United States.

Whatever issues it focused on, this US-born sociolinguistics subsequently became a global discipline, in part occluding the intellectual currents that flowed into sociolinguistics from previous European socially inflected linguistics, and from the study of language in the context of spaces opened for research by colonialism and in disciplinary frames such as anthropology. This is not to dismiss the importance of the political concerns of sociolinguistics within the United States, but rather to question how they travel and are translated into other sociopolitical and national contexts. One key concept in this global discussion is race, for which the US understanding of this term is quite distinct from base-line identity concepts in states which have formal classification regimes such as Vietnam and China. These tend to be based on mother tongue and other cultural attributes.

\section{Concluding thoughts}

Much of the literature on the founding of sociolinguistics is purely celebratory, and primarily biographical or autobiographical. Further close critical readings of the institutional history of sociolinguistics along the lines pursued by Heller would be welcome, particularly at a time of internal disorientation within the field (see Pennycook 2006). It would be interesting to understand further the institutional and funding politics behind the subsequent trajectory of sociolinguistics. The post-World War II history of anthropology is instructive in this regard, with its series of methodological crises and internal battles over epistemological claims to an understanding of the Other. Sociolinguistics largely retains a belief in linguistic analysis as method, a belief that also demarcates an autonomous disciplinary space distinct from ethnography and anthropology, and underwrites claims to engagement in applied or forensic contexts. However, this sits uncomfortably alongside increasingly strong currents of postcolonial reflexivity, theoretical and postmodern skepticism within the discipline. At this complex moment in its history, a rigorous look at the origins of sociolinguistics takes on a special significance. 


\section{References}

Cohn, Bernard. 1996. Colonialism and its forms of knowledge: The British in India. Princeton, NJ: Princeton University Press.

Knight, Chris. 2018. Decoding Chomsky: Science and revolutionary politics. New Haven, CT: Yale University Press.

Pennycook, Alistair. 2006. Mobile Times, Mobile Terms: The Trans-Super-Poly-Metro Movement. In Nikolas Coupland (ed.), Sociolinguistics: Theoretical debates, 201-216. Cambridge: Cambridge University Press.

Robin, R.H. 1997. A short history of linguistics. London: Longmans.

Sampson, Geoffrey. 1980. Schools of linguistics. Stanford, CA: Stanford University Press.

Article note: This essay was originally published in Items: Insights from the Social Sciences, a publication of the Social Science Research Council. Hutton, Christopher. "Linguistics and the State: How Funding and Politics Shape a Field." In "Sociolinguistic Frontiers." Series, Items: Insights from the Social Sciences. https://items.ssrc.org/sociolinguistic-frontiers/linguisticsand-the-state-how-funding-and-politics-shape-a-field/. Reprinted with permission. 